\title{
Inert Materials as Long-Term Carriers and Disseminators of Viable Leptosphaeria maculans Ascospores and Wider Implications for Ascomycete Pathogens
}

Papori Barua and Ming Pei You, School of Agriculture and Environment and the UWA Institute of Agriculture, Faculty of Science, The University of Western Australia, Crawley, WA 6009, Australia; Kirsty L. Bayliss, School of Veterinary and Life Sciences, Murdoch University, WA 6150, Australia; Vincent Lanoiselet, Department of Primary Industries and Regional Development Western Australia, South Perth, WA 6151, Australia; and Martin J. Barbetti, ${ }^{\dagger}$ School of Agriculture and Environment and the UWA Institute of Agriculture, Faculty of Science, The University of Western Australia

\begin{abstract}
The viability of ascospores of the Phoma stem canker (blackleg) pathogen, Leptosphaeria maculans, was tested on a range of carrier materials, including metals, fabrics, woods, and plastics, and under different temperature conditions of 23 and 4,36 and 14 , and 45 and $15^{\circ} \mathrm{C}$ day and night, respectively. At 23 and $4^{\circ} \mathrm{C}$ (day and night, respectively), ascospores remained viable for up to 240 days on Tasmanian oak (Eucalyptus regnans) and pine wood (Pinus radiata). At 36 and $14^{\circ} \mathrm{C}$ (day and night, respectively), ascospores remained viable on pine wood for up to 180 days. At 45 and $15^{\circ} \mathrm{C}$ (day and night, respectively), ascospores remained viable up to 60 days on jute. There were also significant differences $(P<0.001)$ between carrier materials in their abilities to retain ascospores following washing. At least $30 \%$ of intact ascospores recovered from inert carrier

materials were able to germinate on artificial growth media within $48 \mathrm{~h}$ of recovery and some ascospores were still viable after 240 days. These findings confirm that $L$. maculans ascospores remain viable for a much longer time in the absence of a host than previously considered. This demonstrates the importance of inert materials as long-term and longdistance carriers of viable $L$. maculans ascospores, and highlights their potential role for spread of $L$. maculans races to new regions and countries via farming equipment, clothing, and other associated materials Local, national, and international biosecurity agencies need to be aware that the risks of spread of ascomycete plant, animal, and human pathogens via inert materials are significantly greater than currently assessed.
\end{abstract}

Leptosphaeria maculans (Phoma stem canker, blackleg) is the most important disease of oilseed rape and canola (Brassica napus) in many countries (Fitt et al. 2006; Johnson and Lewis 1994; West et al. 2001), including Australia (Barbetti and Khangura 1999; Li et al. 2006a; Sivasithamparam et al. 2005). Despite the availability of plant resistance in some varieties and widespread use of fungicides, Phoma stem canker causes significant production losses in Australia (Barbetti and Khangura 1999) and elsewhere (West et al. 2001). The estimated annual loss from Phoma stem canker to the Australian oilseed rape industry is approximately $\$ 77$ million (Murray and Brennan 2012).

The primary source of L. maculans inoculum is from winddispersed, sexually produced ascospores released from pseudothecia on infested canola stubble (Li et al. 2004, 2006a; McGee and Petrie 1979; Wherrett et al. 2003, 2004). L. maculans ascospores primarily infect seedlings initially, and cause lesions on cotyledons, leaves, and stems (Barbetti 1976; McGee and Petrie 1979). Infections are primarily through stomata or wounds ( $\mathrm{Li}$ et al. 2004). In Australia, although L. maculans ascospores are discharged throughout the growing season, there are distinct ascospore emission peaks in late autumn and early winter (Khangura et al. 2007; Salam et al. 2003, 2007; Savage et al. 2012), the timing of which are dependent on geographic region

${ }^{\dagger}$ Corresponding author: M. J. Barbetti; E-mail: martin.barbetti@uwa.edu.au

Funding: We greatly appreciate the scholarship provided by the Plant Biosecurity Cooperative Research Centre (PBCRC), Bruce, ACT 2617, Australia, for project CRC62042: "Curtailing and managing exotic fungal ascospores incursion into Australia", and the financial support by the School of Plant Biology at the University of Western Australia.

Accepted for publication 7 November 2017.

C 2018 The American Phytopathological Society and time of the year (Savage et al. 2013), and also on seasonal rainfall and temperatures (Salam et al. 2003, 2007). In the Mediterraneantype environment of southwest and southern Australia (Barbetti et al. 2012), release of $L$. maculans ascospores can be diurnal (Savage et al. 2010, 2012).

Survival of L. maculans on canola residues depends on the environmental conditions (Huang et al. 2003; West and Fitt 2005). Pseudothecia can remain viable for up to 4 years where dry summers predominate such as in Western Australia but only up to approximately 2 years in mild or wet conditions such as those in the United Kingdom (West et al. 1999, 2001). Infested residues are the primary source of inoculum for successive spread of the disease from season to season and between different areas (Huang et al. 2003; West et al. 1999). Li et al. (2007) highlighted the high relative importance of ascospore survival in soil in the disease epidemiology in situations where the ascospore showers have been little or infrequent, particularly if restricted to a short period at the beginning of growing season. However, survivability of ascospores has been reported to decrease both over time (Li et al. 2007) and with increased temperature (Huang et al. 2003).

L. maculans can be transmitted through the seed (Lloyd 1959), and Wood and Barbetti (1977) observed that both pods and seed can be infected by L. maculans. At least $36 \%$ infected seed gave rise to mature infected plants, indicating that seedborne infection of L. maculans can play an important role in spreading the pathogen into fields of susceptible hosts (Wood and Barbetti 1977).

Recently, we developed a rapid and miniaturized system using Alamar Blue (resazurin dye; 7-hydroxy-3H-phenoxazin-3-one 10oxide) for assessing fungal spore viability and, for developing this methodology, we used L. maculans as the "model pathogen" across six different carrier materials and made comparisons with Kabatiella caulivora, Magnaporthe oryzae, Puccinia striiformis f. sp. tritici, and the yeast Saccharomyces cerevisiae to prove its wider applicability (Barua et al. 2017a,b). However, what has never been properly investigated in detail is the potential for wider dissemination of new pathogen races of L. maculans (Balesdent et al. 2005) via attachment 
to a comprehensive range of different inert carrier materials and under different temperature regimes, as would be associated with movement of humans, farming equipment, clothing, and commodities across regions and continents. In addition, although temperature is known to play an important role in formation and establishment of stem cankers and consequent disease severity (Barbetti 1975; Li et al. 2006b), its role in ascospore survival has not been investigated in terms of survival on inert carrier materials.

Although the movement of this pathogen through infected seed or infested crop debris is a well-recognized risk (Fitt et al. 2006), alternative means of movement and entry of $L$. maculans through attachment to different carrier materials used in everyday life, found around farms, associated in one way or another in the cargo and transport industry, or commonly used by travelers, also needs to be investigated. In order to fully understand the potential risks from and role of Phoma stem canker spread by L. maculans ascospores, we undertook studies into the long-term viability of $L$. maculans ascospores on a range of 15 different inert carrier materials and under three different temperature regimes.

\section{Materials and Methods}

Inoculum preparation. L. maculans ascospores were produced from collected stubble carrying mature pseudothecia from previously infested fields in early winter and stored dry at $25^{\circ} \mathrm{C}$ for a few weeks until needed. Ascospores were produced following the protocol of $\mathrm{Li}$ et al. (2004). Briefly, infected stubble pieces were immersed in $10 \mathrm{ml}$ of sterile deionized (DI) water in covered Petri plates for $1 \mathrm{~h}$ at $25^{\circ} \mathrm{C}$ under fluorescent light and then maintained at $4^{\circ} \mathrm{C}$ in the dark for $1 \mathrm{~h}$. Ascospores were collected by washing them off the inside of the Petri plate lids with DI water. The concentration of released ascospores was measured using a hemocytometer (Superior Marienfeld).

Selection of carrier materials. In total, 15 different carrier materials were selected to determine their effectiveness as potential spore carriers and any direct effects of the materials upon spore survival. These were metals (aluminum, brass, corrugated iron sheet, galvanized steel, painted steel, and zinc) fabrics (denim, fleece, silk, and fiber polyester) woods (Pinus radiata [pine] and Eucalyptus regnans [Tasmanian oak]), and miscellaneous (glass, jute, and plastic). These were selected as test materials because they are common, everyday materials used around farms or used in everyday life, found around farms or associated in one way or another in the cargo and transport industry, or commonly used by travelers.

Inoculations of carrier materials and measurement of survival of $\boldsymbol{L}$. maculans ascospores over time at different temperatures. The sterile test materials were organized in sterile Petri dishes and inoculated according to Barua et al. (2017a). The materials were cut into $0.5-\mathrm{cm}$ squares and autoclaved, and the sterile materials were randomly placed into rows in sterile 48 -well cell culture plates (Greiner 48 sterile). The material in each well was inoculated individually with $10 \mu \mathrm{l}$ of inoculum $\left(10^{6}\right.$ ascospores $\left.\mathrm{ml}^{-1}\right)$ and allowed to dry in a laminar flow for 2 to $3 \mathrm{~h}$. Inoculated culture plates were placed under one of the three controlled environmental conditions: $23 \pm 1^{\circ} \mathrm{C}$ (day) and $8 \pm 1^{\circ} \mathrm{C}$ (night), $36 \pm 1^{\circ} \mathrm{C}$ (day) and $14 \pm 1^{\circ} \mathrm{C}$ (night), or $45 \pm 1^{\circ} \mathrm{C}$ (day) and $15 \pm 1^{\circ} \mathrm{C}$ (night). Conditions were based on 10 years of maximum and minimum climate data 2005 to 2014 to represent the highest, lowest, and intermediate maximum and minimum temperature combinations for winter, summer, and autumn to spring, respectively, in Western Australia. Photoperiod was 14 and $10 \mathrm{~h}$ for day and night, respectively, using a light source of LED cool white and incandescent light bulbs with an intensity of 250, 260, or $320 \mu \mathrm{mol} \mathrm{m} \mathrm{m}^{-2} \mathrm{~s}^{-1}$, respectively (Quantum Flux MQ100; Apogee). Relative humidity in controlled environmental rooms was approximately 20 and $25 \%$ during the day and night, respectively. There were six replicates in different 48 -well culture plates for each inoculated carrier material and noninoculated control material, with every sampling time and each temperature treatment arranged in a fully randomized design to measure the effect of temperature and time on ascospore viability. The experiment was run over 270 days, with sampling to assess the effect of time and temperature on viability of ascospores and the ability of the materials to retain or release viable urediniospores starting daily from day 1 until day 7 , then weekly until day 30 , after which sampling was undertaken at regular 30-day intervals, concluding at day 270 , until no viability was observed.

Recovery of $\boldsymbol{L}$. maculans ascospores from inoculated carrier materials and determination of viability. The ascospores were recovered from the carrier materials and the numbers and their viability were assessed according to Barua et al. (2017a). Briefly, ascospores were recovered from the carrier materials by adding $800 \mathrm{ml}$ of $0.1 \%$ Tween 20 directly to each well of the treatment plates and placing the plates on a rotary shaker for $40 \mathrm{~min}$ at $700 \mathrm{rpm}$. After washing, the carrier materials were removed from the residual ascospore suspension and prepared for microscopy. The Alamar Blue bioassay was optimized as a viability indicator for ascospores of $L$. maculans and the optimum time for maximum metabolic activity was 2 h. $L$. maculans ascospore suspensions, ranging in concentration from $10^{7} \mathrm{ml}^{-1}$ to $10 \mathrm{ml}^{-1}$ by 10 -fold serial dilution, were used as comparison standards. Three replicate wells were used for each concentration and were set up using $100 \mu \mathrm{l}$ of fresh ascospores for the standards, with $20 \mu \mathrm{l}$ of Alamar Blue reagent. In the same way, residual ascospore solutions after washing were set up with $100 \mu$ l of residual solution or wash suspension containing ascospores with $20 \mu \mathrm{l}$ of Alamar Blue reagent. Negative controls contained $100 \mu \mathrm{l}$ of DI water and $20 \mu$ l of Alamar Blue reagent to determine the extent of any background absorbance. The absorbance at $600 \mathrm{~nm}$ (A600) and $570 \mathrm{~nm}$ (A570) was measured using a spectrophotometer (Thermo Scientific Multiskan Spectrum). The average of the background A600 for control wells was subtracted from all A570 of experimental wells. A standard curve of A570 nm minus A600 nm versus concentration of ascospores was plotted and used to calculate the percentage viability of $L$. maculans ascospores in residual solutions after washing. The percentage of viable ascospores was determined for each replicate using the regression equation from the standard curve, and the mean was calculated from the six replicates. The correlation between the germinated ascospores and the viability assay was also determined.

Observation of germination of ascospores on test materials. Fresh ascospores as controls were germinated on half-strength potato dextrose agar (1/2 PDA) to observe the percent viability under a compound microscope at regular time intervals of $6,12,24,48$, and $72 \mathrm{~h}$. Similarly, using the same time intervals, the number of ascospores germinated on the test carrier materials was also calculated, using a hemocytometer counting chamber under a compound microscope, for ascospore suspensions recovered after washing the test materials until no further germinated spores were recovered from the inoculated materials. Any nongerminated intact or broken ascospores recovered from materials after washing were also plated on 1/2 PDA to assess their ability to germinate. The germination of the treated ascospores on the materials or on 1/2 PDA was compared with germination of the fresh ascospores used as a control, with maximum germination of the control ascospores at $90 \%$ by $48 \mathrm{~h}$ and no further increase by $72 \mathrm{~h}$.

Experimental design and data analyses. All experiments were arranged using a completely randomized design, repeated twice, with six replications for each of the three temperatures. The relationship between the initial and repeat experiments was assessed using a paired $t$ test using GenStat and for homogeneity of variances across the original and repeat experiments using Bartlett's test (Snedecor and Cochran 1989). In each case, there were no significant differences between each pair of experiments $(P>0.05)$ using $t$ test and variances were similar using Bartlett's test; therefore, the data sets were pooled, reanalyzed, and presented as a single data set.

\section{Results}

At 23 and $8^{\circ} \mathrm{C}$ (day and night, respectively), viable ascospores were recovered for up to 240 days from Tasmanian oak and pine; 180 days from jute and from painted steel; 150 days on silk; 120 days on corrugated iron sheet, denim, and glass; 90 days on plastic, 60 days from fiber polyester and brass; 30 days from fleece; and up to 21 days from galvanized steel. At 36 and $14^{\circ} \mathrm{C}$ (day and night, respectively), viable 
ascospores were recovered for up to 180 days from pine; 90 days from painted steel; 60 days on aluminum, fiber polyester, jute, and zinc; 30 days on brass, fleece, and Tasmanian oak; 21 days on denim and silk; 14 days on corrugated iron sheet; up to 7 days on plastic; and up to 6 days on galvanized steel and glass. At 45 and $15^{\circ} \mathrm{C}$ (day and night, respectively), viable ascospores were recovered for up to 60 days on jute; 21 days on denim and silk; 14 days on fiber polyester; 7 days on pine; 6 days on plastic, painted steel, and Tasmanian oak; 5 days on corrugated iron sheet, glass, and zinc; 4 days on aluminum and fleece; and up to 3 days on brass and 2 days on galvanized steel.

Specific differences in decrease in ascospore viability for each carrier material are provided as follows.

Metals. At 23 and $8^{\circ} \mathrm{C}$ (day and night, respectively), after 1 day, the viability of the ascospores decreased by $70 \%$ on aluminum, galvanized sheet, and zinc; $75 \%$ on painted steel; $80 \%$ on corrugated iron sheet; and $90 \%$ on brass. Ascospore viability for each type of metal carrier material decreased by $99 \%$ within a time period of 180 days. By day 7 , there was a decline in viability of the ascospores up to 85 to $90 \%$ on all the metals at 23 and $8{ }^{\circ} \mathrm{C}$ (day and night, respectively). At 36 and $14^{\circ} \mathrm{C}$ (day and night, respectively), ascospore viability declined by $75 \%$ on aluminum and zinc; $90 \%$ on brass, corrugated iron sheet, and painted steel; and $98 \%$ on galvanized sheet after day 1. A $99 \%$ decrease in spore viability was observed by day 90 on painted steel, day 60 on zinc, day 30 on aluminum and brass, day 14 on corrugated iron sheet, and day 6 on galvanized sheets, with no further viability observed subsequently. The percentage of viable spores at 45 and $15^{\circ} \mathrm{C}$ (day and night, respectively) decreased by $81 \%$ on zinc; $90 \%$ on aluminum, corrugated iron sheet, and painted steel; and $99 \%$ on brass and galvanized sheet after day 1 . Viability of spores decreased by $98 \%$ at
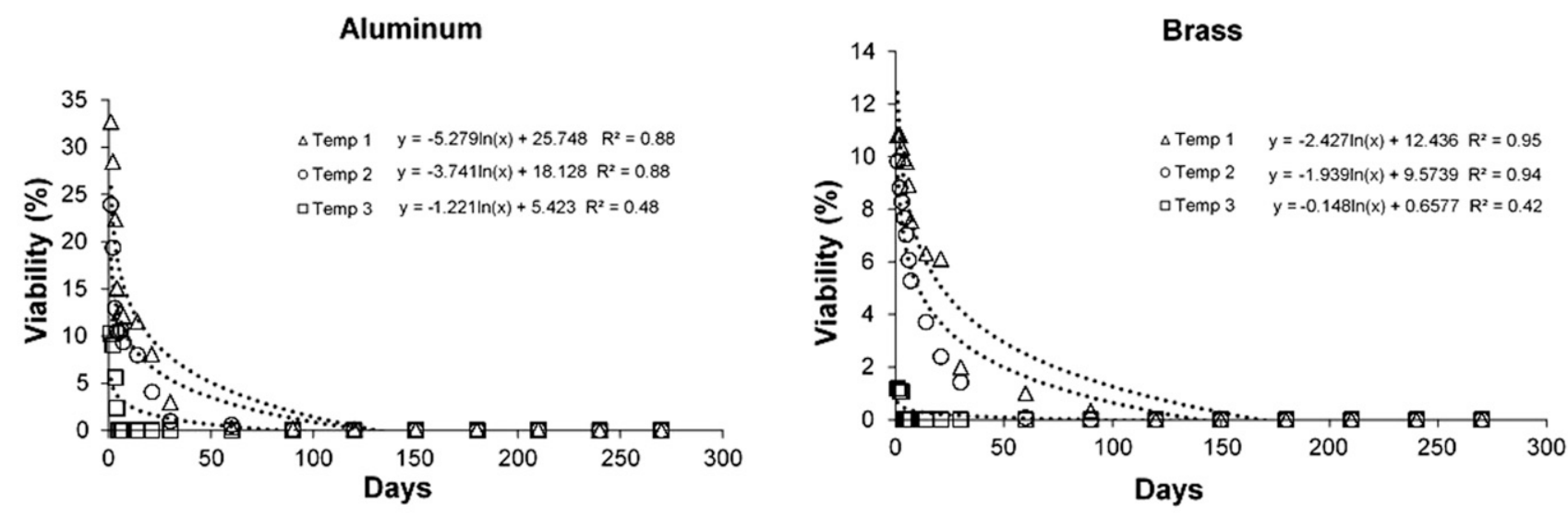

Corrugated iron sheet

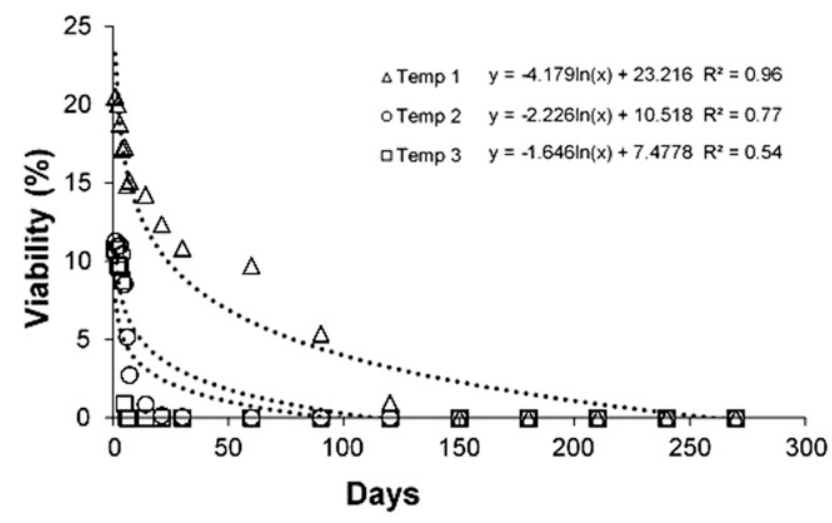

Galvanized steel

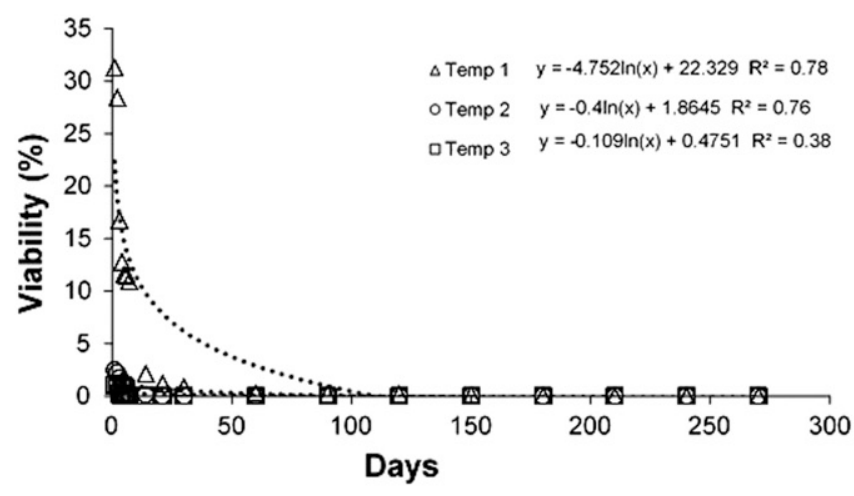

Painted steel
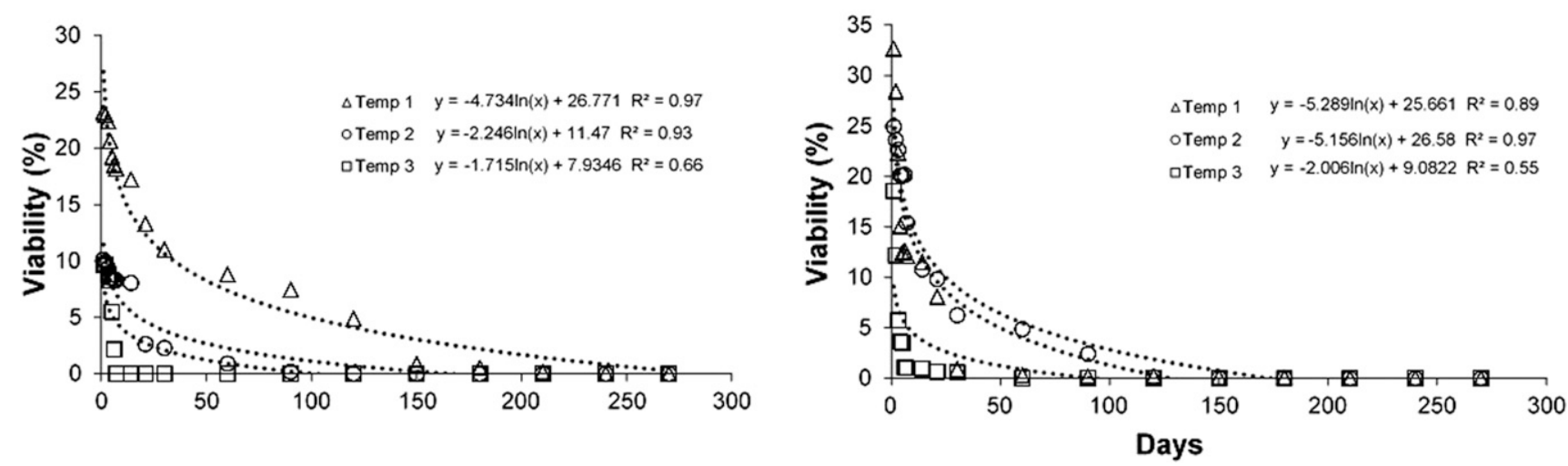

Fig. 1. Maximum percentage of viable Leptosphaeria maculans ascospores recovered from metals (aluminum, brass, corrugated iron sheet, galvanized steel, painted steel, and zinc) at three different temperature regimes (Temp $1=23$ and 8 , Temp $2=36$ and 14 , and Temp $3=45$ and $15^{\circ} \mathrm{C}$, day and night, respectively) and the ability of the materials to retain or release viable ascospores over time. Regression analysis was undertaken with a logarithmic model $\left(\log _{2}\right)$ to define trend lines for each test material at each temperature regime. Parameters that define slope, y-intercept, asymptotes, and $R^{2}$ are presented for each test material for each temperature regime. 
6 days on painted steel and at 4 days on aluminum and $99 \%$ at day 5 on zinc and day 1 on brass and galvanized sheet (remained $99 \%$ till day 3 and 2, respectively), with no further viability observed subsequently (Fig. 1).

Fabrics. At 23 and $8^{\circ} \mathrm{C}$ (day and night, respectively), the viability of spores from silk decreased by $45 \%$ on silk, $62 \%$ on denim and fiber polyester, and $65 \%$ on fleece material after day 1 . The viability of the ascospores decreased by $99 \%$ on day 150 on silk, day 120 on denim, day 60 on fiber polyester, and day 30 on fleece, with just 1 week with no viable spores recovered subsequently. At 36 and $14^{\circ} \mathrm{C}$ (day and night, respectively), viability of ascospores after day 1 decreased by $62 \%$ on silk, $70 \%$ viability on denim and fiber polyester, and $85 \%$ on fleece. The viability of the ascospores decreased to $99 \%$ by day 60 on fiber polyester, day 30 on fleece, and day 21 on denim and silk, with no viable spores recovered subsequently. At 45 and $15^{\circ} \mathrm{C}$ (day and night, respectively), the viability of the ascospores decreased by $86 \%$ on silk, $90 \%$ on denim and fiber polyester, and $96 \%$ on fleece after day 1 , with a further decrease to $99 \%$ by day 21 on denim and silk, day 14 fiber polyester, and day 4 on fleece, with no viability recorded subsequently after these time periods (Fig. 2).

Woods. At 23 and $8^{\circ} \mathrm{C}$ (day and night, respectively), the viability of the ascospores decreased by $39 \%$ on pine wood and by $49 \%$ on Tasmanian oak wood after day 1 , with a further decrease in viability by $97 \%$ by day 240 on both pine and Tasmanian oak, with no further viability observed subsequently. At 36 and $14^{\circ} \mathrm{C}$ (day and night, respectively), viability of ascospores after day 1 decreased by $68 \%$ on pine wood and by $70 \%$ on Tasmanian oak wood, with $99 \%$ decrease in viability on day 60 on pine and day 30 on Tasmanian oak. At 45 and $15^{\circ} \mathrm{C}$ (day and night, respectively), the viability of the ascospores decreased by $81 \%$ on pine and $83 \%$ after day 1 , with a further decrease in viability by $99 \%$ on day 7 on pine and $97 \%$ on Tasmanian oak on day 6, with no viability recorded subsequently (Fig. 3).

Miscellaneous. At 23 and $8^{\circ} \mathrm{C}$ (day and night, respectively), the viability of the ascospores decreased by $57 \%$ on jute, $69 \%$ on glass, and $71 \%$ on plastic. A $99 \%$ decline in viability was observed by day 180 on jute, day 120 on glass, and day 90 on plastic, with no viability recorded after that. At 36 and $14^{\circ} \mathrm{C}$ (day and night, respectively), viability of ascospores after day 1 decreased by $75 \%$ on jute, $93 \%$ on glass, and $94 \%$ on plastic, with $99 \%$ decrease in viability by day 60 on jute, day 7 on plastic, and day 6 on glass, with no further viability recorded. At 45 and $15^{\circ} \mathrm{C}$ (day and night, respectively), the viability of the ascospores decreased by $89 \%$ on jute and $97 \%$ on glass and plastic after day 1, with further decrease in viability by $97 \%$ on day 7 on jute and $99 \%$ on glass and plastic on day 5 and 6 , respectively, with no further viability detected (Fig. 4).

Observation of germination of ascospores on test materials. The mean maximum germination of the control ascospores was $90 \%$ and obtained within a time period of 24 to $48 \mathrm{~h}$ on $1 / 2$ PDA (Table 1). There was no change in the germination of control ascospores after that time point. In comparison with control ascospore germination, ascospore germination was $1 \%$ on metals, $5 \%$ on wood, $5 \%$ on fabric, and $2 \%$ on miscellaneous materials, up to $48 \mathrm{~h}$. Maximum germination of the nongerminated intact or broken ascospore suspension recovered after washing or recovery from the different material groups onto $1 / 2$ PDA was $30 \%$ from metals, $50 \%$ from woods, $51 \%$ from fabrics, and $41 \%$ from the miscellaneous materials for the 48-h time period (Table 1). There was strong positive
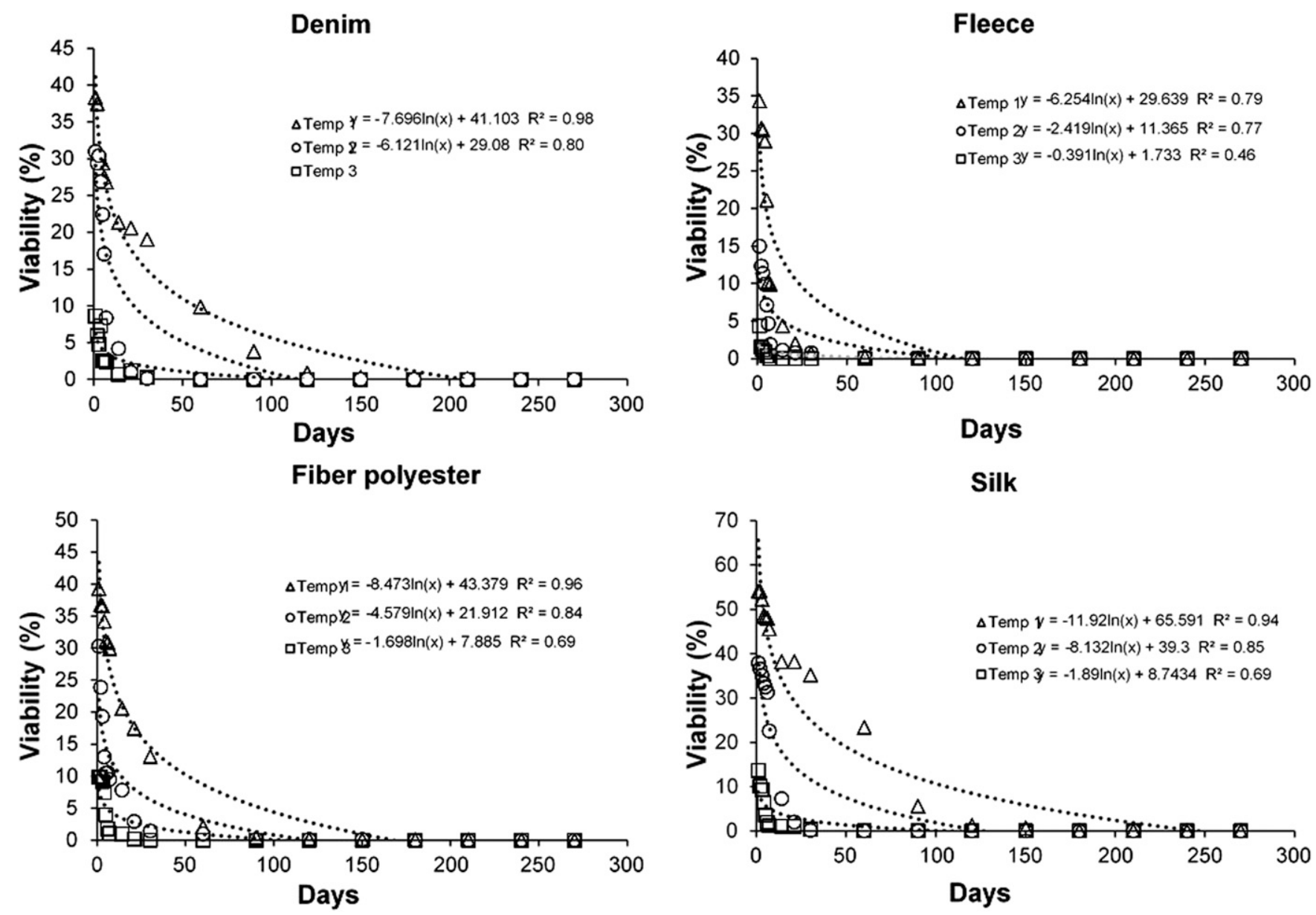

Fig. 2. Maximum percentage of viable Leptosphaeria maculans ascospores recovered from fabrics (denim, fleece, silk, and fiber polyester) at three different temperature regimes (Temp $1=23$ and 8 , Temp $2=36$ and 14 , and Temp $3=45$ and $15^{\circ} \mathrm{C}$, day and night, respectively) and the ability of the materials to retain or release viable ascospores over time. Regression analysis was undertaken with a logarithmic model $\left(\log _{2}\right)$ to define trend lines for each test material at each temperature regime. Parameters that define slope, $y$-intercept, asymptotes, and $R^{2}$ are presented for each test material for each temperature regime. 
correlation between the germinated ascospores and the viability assay $\left(y=0.9901 x+1.2694, P<0.001, R^{2}=0.99\right)$.

\section{Discussion}

This is the first study to confirm the long-term viability of $L$. maculans ascospores on such a wide range of different carrier materials and under different temperature conditions. These results highlight the potential for dissemination of L. maculans on inert carrier materials and, in particular, the role of these materials as an alternative way to spread natural ascospore inoculum to new areas, in the absence of any host plant tissues. At least $30 \%$ of intact ascospores recovered from inert carrier materials were able to germinate on artificial growth media within $48 \mathrm{~h}$ of recovery and some ascospores were still viable after 240 days. Even broken ascospores, following their natural fragmentation at septae, still germinated, particularly from the nonterminal end cells of ascospores. These findings are

\section{Pinus radiata (pine)}



\section{Eucalyptus regnans (Tasmanian oak)}

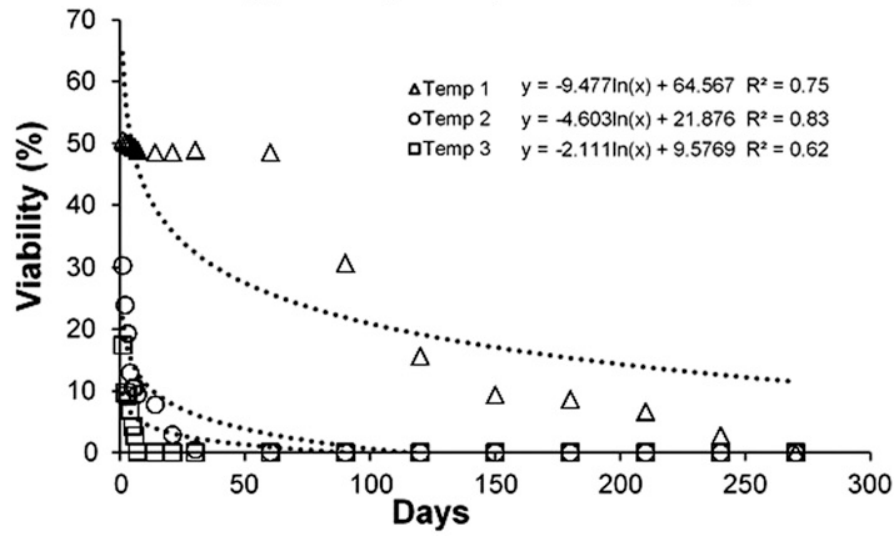

Fig. 3. Maximum percentage of viable Leptosphaeria maculans ascospores recovered from woods (Pinus radiata [pine] and Eucalyptus regnans [Tasmanian oak]) at three different temperature regimes (Temp $1=23$ and 8 , Temp $2=36$ and 14 , and Temp $3=45$ and $15^{\circ} \mathrm{C}$, day and night, respectively) and the ability of the materials to retain or release viable ascospores over time. Regression analysis was undertaken with a logarithmic model $\left(\log _{2}\right)$ to define trend lines for each test material at each temperature regime. Parameters that define slope, y-intercept, asymptotes, and $R^{2}$ are presented for each test material for each temperature regime.

Plastic
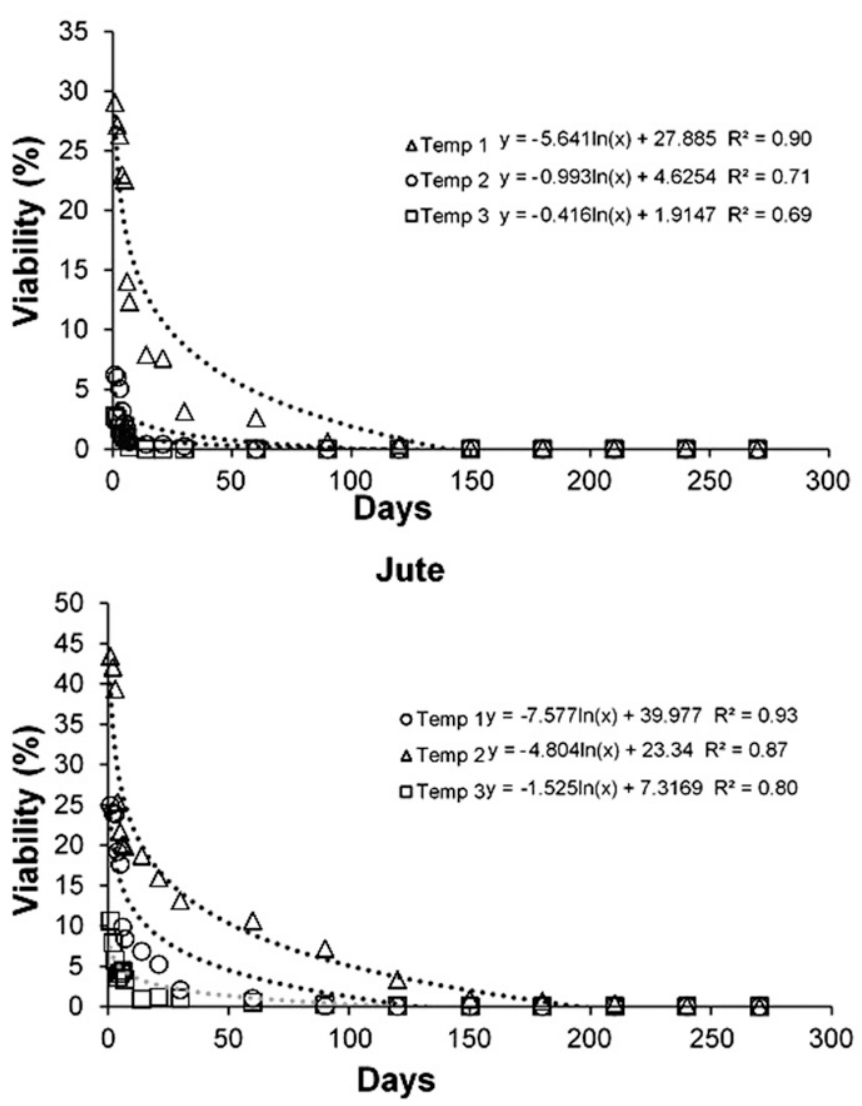

Glass



Fig. 4. Maximum percentage of viable Leptosphaeria maculans ascospores recovered from miscellaneous materials (glass, jute, and plastic) at three different temperature regimes (Temp $1=23$ and 8 , Temp $2=36$ and 14 , and Temp $3=45$ and $15^{\circ} \mathrm{C}$, day and night, respectively) and the ability of the materials to retain or release viable ascospores over time. Regression analysis was undertaken with a logarithmic model $\left(\log _{2}\right)$ to define trend lines for each test material at each temperature regime. Parameters that define slope, $y$-intercept, asymptotes, and $R^{2}$ are presented for each test material for each temperature regime. 
important because ascospores play a major role in initiation of Phoma stem canker epidemics, particularly in relation to establishment of the primary infections (Barbetti 1976; Li et al. 2004; West et al. 2001). However, infected oilseed rape debris plays a pivotal role in survival of $L$. maculans and provides the overridingly important primary source of inoculum for successive dissemination across seasons and neighboring regions (Huang et al. 2003; Li et al. 2007; West et al. 1999, 2001). Further, any viable ascospores would have to come into contact with a susceptible host plant and although, in many instances, this may not occur, in others it easily could occur, such as from ascospores on transport containers onto commonly occurring weedy Brassicaceae species in transport depots and on farms and from clothing of returning agricultural workers directly onto Brassica crop or weedy species. As such, the outcomes of the current study are important, because the survival and viability of ascospores subsequent to emission from pseudothecia is crucial in the disease epidemiology.

Intact ascospores were previously known to have some resilience to unfavorable conditions. For example, Huang et al. (2003) showed that, ascospores of $L$. maculans could survive longer than 1 month when exposed to dry air at $20^{\circ} \mathrm{C}$ and Barua et al. (2017a) showed that viability declined rapidly even at favorable conditions of 23 and $8^{\circ} \mathrm{C}$. Furthermore, Huang et al. (2003) found that ascospore viability and infective capabilities were degraded over several weeks by moderately high temperatures (up to $20^{\circ} \mathrm{C}$ ) or lower relative humidity. Savage et al. (2012) were the first to demonstrate that robustness of ascospores provides a distinct advantage and enables $L$. maculans to have a distinct diurnal pattern, with a mid- to late-afternoon peak in ascospore release in Australia coinciding with meteorological conditions of warmer temperatures and lower humidity, because these are more conducive to their greater dispersal over larger distances than for analogous release at other times of the day. Current studies highlight the significant differences between temperature regimes in terms of survival of $L$. maculans ascospores and the combined effects of type of carrier material on the length of prolonged survival. For example, in the current study, at 23 and $8^{\circ} \mathrm{C}$ (day and night, respectively), L. maculans ascospores remained viable on pine wood and Tasmanian oak for up to 240 days. In contrast, at 36 and $14^{\circ} \mathrm{C}$, ascospores could remain viable for up to 180 days but only on pine wood whereas, at 45 and $15^{\circ} \mathrm{C}$, ascospores remained viable for only up to 60 days and only on jute.

The current study has not only demonstrated far greater resilience of $L$. maculans ascospores than previously reported but also has highlighted the "more favorable" inert materials that support this resilience. Clearly, there is a greater risk than previously anticipated for

Table 1. Germination (\%) of ascospores of Leptosphaeria maculans on different test materials and on $1 / 2$ strength potato dextrose agar (1/2 PDA) over $48 \mathrm{~h}^{\mathrm{a}}$

\begin{tabular}{|c|c|c|c|c|}
\hline \multirow[b]{2}{*}{ Germination, materials } & \multicolumn{4}{|c|}{$\begin{array}{c}\text { Germination }(\%) \text { per time } \\
\text { period }\end{array}$} \\
\hline & $6 \mathrm{~h}$ & $12 \mathrm{~h}$ & $24 \mathrm{~h}$ & $48 \mathrm{~h}$ \\
\hline \multicolumn{5}{|c|}{ Germination of ascospores on materials } \\
\hline Metals & 1 & 1 & 1 & 1 \\
\hline Wood & 2 & 4 & 5 & 5 \\
\hline Fabric & 2 & 3 & 5 & 5 \\
\hline Miscellaneous & 1 & 2 & 2 & 2 \\
\hline \multicolumn{5}{|c|}{$\begin{array}{l}\text { Germination of ascospores recovered from } \\
\text { materials on } 1 / 2 \text { PDA }\end{array}$} \\
\hline Metals & 10 & 30 & 30 & 30 \\
\hline Wood & 15 & 50 & 50 & 50 \\
\hline Fabric & 15 & 50 & 51 & 51 \\
\hline Miscellaneous & 10 & 38 & 41 & 41 \\
\hline \multicolumn{5}{|c|}{$\begin{array}{l}\text { Germination of control ascospores on } 1 / 2 \\
\text { PDA }\end{array}$} \\
\hline Control & 15 & 87 & 90 & 90 \\
\hline
\end{tabular}

more widespread dissemination of existing as well as new or different $L$. maculans races into new areas, as a consequence of ascospores remaining intact and viable for long periods in the absence of a susceptible host. Minimizing development and spread of new or different L. maculans races is of critical importance to the long-term viability of the oilseed rape industries around the world (Balesdent et al. 2005), because their spread and build-up drives boom-and-bust cycles of effective and failed host resistance, respectively, both in Australia (Balesdent et al. 2005; Li et al. 2003, 2005, 2008) and elsewhere, such as in France (Rouxel and Balesdent 2017).

The current studies also highlight the threat of dispersion not only of L. maculans as an important plant pathogen but also, potentially, other important ascomycete plant and animal or human pathogens. Destructive ascomycete plant pathogen examples include wheat scab and Dutch elm disease, while human ascomycete pathogens include the etiological agent of thrush, the yeast Candida albicans, and the dermatophytes causing athlete's foot (Berbee 2001). Hence, the current study also emphasizes the broader biosecurity implications in relation to the overall transport and movement of ascospores via these carrier materials, highlighting significant potential for ascomycete pathogens in general being spread widely in association with movement of humans, farming equipment, clothing, and commodities across regions and continents. The relative risks will be commensurate with the relative abilities of the different carrier materials to retain ascospores, the relative survival capabilities of different ascomycete pathogens, and the relative comparative risks of other pathways of entry such as imported infected seed or seed infested with crop residues. That not all $L$. maculans ascospores could be removed from the carrier materials even after washing the materials highlights the challenges in eliminating ascomycete ascospore contamination from equipment, clothes, travelers, wood, crafts, and toys. Furthermore, it highlights to local, national, and international biosecurity agencies that the risk of spread of ascomycete plant, animal, and human pathogens via inert materials are significantly greater than current assessments suggest.

\section{Acknowledgments}

We thank R. Creasy and B. Piasini from the University of Western Australia for support and help with these controlled environment studies.

\section{Literature Cited}

Balesdent, M. H., Barbetti, M. J., Li, H., Sivasithamparam, K., Gout, L., and Rouxel, T. 2005. Analysis of Leptosphaeria maculans race structure in a world-wide collection of isolates. Phytopathology 95:1061-1071.

Barbetti, M. J. 1975. Effects of temperature on development and progression in rape of crown canker caused by Leptosphaeria maculans. Aust. J. Exp. Agric. Anim. Husb. 15:705-708.

Barbetti, M. J. 1976. The role of pycnidiospores of Leptosphaeria maculans in the spread of blackleg disease in rape. Aust. J. Exp. Agric. Anim. Husb. 16: 911-914.

Barbetti, M. J., Banga, S. S., and Salisbury, P. A. 2012. Challenges for crop production and management from pathogen biodiversity and diseases under current and future climate scenarios - case study with oilseed Brassicas. Field Crops Res. 127:225-240.

Barbetti, M. J., and Khangura, R. K. 1999. Managing blackleg in the disease-prone environment of Western Australia. In: Proc. 10th Int. Rapeseed Cong. Canberra, Australia.

Barua, P., You, M. P., Bayliss, K., Lanoiselet, V., and Barbetti, M. J. 2017a. A rapid and miniaturized system using Alamar Blue to assess fungal spore viability: Implications for biosecurity. Eur. J. Plant Pathol. 148:139-150.

Barua, P., You, M. P., Bayliss, K., Lanoiselet, V., and Barbetti, M. J. 2017b. Long term viability of the northern anthracnose pathogen, Kabatiella caulivora, facilitates its transportation and spread. Plant Pathol. 66:1463-1471.

Berbee, M. L. 2001. The phylogeny of plant and animal pathogens in the Ascomycota. Physiol. Mol. Plant Pathol. 59:165-187.

Fitt, B. D. L., Brun, H., Barbetti, M. J., and Rimmer, S. R. 2006. World-wide importance of Phoma stem canker (Leptosphaeria maculans and L. biglobosa) on oilseed rape (Brassica napus). Eur. J. Plant Pathol. 114:3-15.

Huang, Y. J., Fitt, B. D. L., and Hall, A. M. 2003. Survival of A-group and B-group Leptosphaeria maculans (Phoma stem canker) ascospores in air and mycelium on oilseed rape stem debris. Ann. Appl. Biol. 143:359-369.

Johnson, R. D., and Lewis, B. G. 1994. Variation in host range, systemic infection and epidemiology of Leptosphaeria maculans. Plant Pathol. 43:269-277.

Khangura, R., Speijers, J., Barbetti, M. J., Salam, M. U., and Diggle, A. J. 2007. Epidemiology of blackleg (Leptosphaeria maculans) of canola (Brassica napus L.) in relation to maturation of pseudothecia and discharge of ascospores in Western Australia. Phytopathology 97:1011-1021. 
Li, C. X., Wratten, N., Salisbury, P., Burton, W., Potter, T., Walton, G. W., Sivasithamparam, K., Banga, S., Singh, D., Liu, S., Fu, T., and Barbetti, M. J. 2008. Response of Brassica napus and B. juncea germplasm from Australia, China and India to Australian populations of Leptosphaeria maculans. Australas. Plant Pathol. 37:162-170.

Li, H., Barbetti, M. J., and Sivasithamparam, K. 2005. Hazard from reliance on cruciferous hosts as sources of major gene based resistance for managing blackleg (Leptosphaeria maculans) disease. Field Crops Res. 91:185-198.

Li, H., Sivasithamparam, K., and Barbetti, M. J. 2003. Breakdown of a Brassica rapa subsp. sylvestris single dominant blackleg resistance gene in B. napus by Leptosphaeria maculans field isolates in Australia. Plant Dis. 87:752.

Li, H., Sivasithamparam, K., and Barbetti, M. J. 2006a. Evidence supporting the polycyclic nature of blackleg disease (Leptosphaeria maculans) of oilseed rape in Australia and implications for disease management. Brassica 8:65-69.

Li, H., Sivasithamparam, K., and Barbetti, M. J. 2007. Soilborne ascospores and pycnidiospores of Leptosphaeria maculans can contribute significantly to blackleg disease epidemiology in oilseed rape (Brassica napus) in Western Australia. Australas. Plant Pathol. 36:439-444.

Li, H., Sivasithamparam, K., Barbetti, M. J., and Kuo, J. 2004. Germination and invasion by ascospores and pycnidiospores of Leptosphaeria maculans on spring-type Brassica napus canola varieties with varying susceptibility to blackleg. J. Gen. Plant Pathol. 70:261-269.

Li, H., Smyth, F., Barbetti, M. J., and Sivasithamparam, K. 2006b. Relationship between Brassica napus seedling and adult plant responses to Leptosphaeria maculans is determined by plant growth stage at inoculation and temperature regime. Field Crops Res. 96:428-437

Lloyd, A. B. 1959. The transmission of Phoma lingam (Tode) Desm. in the seeds of swede, turnip, chou moellier, rape and kale. N. Z. J. Agric. Res. 2:649-658.

McGee, D. C., and Petrie, G. A. 1979. Seasonal patterns of ascospore discharge by Leptosphaeria maculans in relation to blackleg of oilseed rape. Phytopathology 69:586-589.

Murray, G. M., and Brennan, J. P. 2012. The Current and Potential Costs from Diseases of Oilseed Crops in Australia. GRDC Research Code: CER00002. Grains Research and Development Corporation, Australia. https://grdc.com. au/_data/assets/pdf_file/0021/82641/grdcreportdiseasecostoilseedspdf.pdf.pdf

Rouxel, T., and Balesdent, M. H. 2017. Life, death and rebirth of avirulence effectors in a fungal pathogen of Brassica crops, Leptosphaeria maculans. New Phytol. 214:526-532.

Salam, M. U., Fitt, B. D. L., Aubertot, J.-N., Diggle, A. J., Huang, Y. J., Barbetti, M. J., Gladders, P., Jedryczka, M., Khangura, R. K., Wratten, N., Fernando, W. G. D., Penaud, A., Pinochet, X., and Sivasithamparam, K. 2007. Two weather-based models for predicting the onset of seasonal release of ascospores of Leptosphaeria maculans or L. biglobosa. Plant Pathol. 56:412-423.

Salam, M. U., Khangura, R. K., Diggle, A. J., and Barbetti, M. J. 2003. Blackleg Sporacle: A model for predicting onset of pseudothecia maturity and seasonal ascospore showers in relation to blackleg of canola. Phytopathology 93 1073-1081.

Savage, D., Barbetti, M. J., MacLeod, W. J., and Salam, M. U. 2010. Timing of propagule release significantly alters the deposition area of resulting aerial dispersal. Divers. Distrib. 16:288-299.

Savage, D., Barbetti, M. J., MacLeod, W. J., Salam, M. U., and Renton, M. 2012. Seasonal and diurnal patterns of spore release can significantly affect the proportion of spores expected to undergo long-distance dispersal. Microb. Ecol. 63:578-585.

Savage, D., Barbetti, M. J., MacLeod, W. J., Salam, M. U., and Renton, M. 2013. Temporal patterns of ascospore release in Leptosphaeria maculans vary depending on geographic region and time of observation. Microb. Ecol. 65 584-592.

Sivasithamparam, K., Barbetti, M. J., and Li, H. 2005. Recurring challenges from a necrotrophic fungal plant pathogen: A case study with Leptosphaeria maculans (causal agent of blackleg disease in Brassicas) in Western Australia. Ann. Bot. 96:363-377.

Snedecor, G. W., and Cochran, W. G. 1989. Statistical Methods, 8th ed. Iowa State University Press, Ames, IA.

West, J. S., Biddulph, J. E., Fitt, B. D. L., and Gladders, P. 1999. Epidemiology of Leptosphaeria maculans in relation to forecasting stem canker severity on winter oilseed rape in the UK. Ann. Appl. Biol. 135:535-546.

West, J. S., and Fitt, B. D. L. 2005. Population dynamics and dispersal of Leptosphaeria maculans (blackleg of canola). Australas. Plant Pathol. 34:457-461.

West, J. S., Kharbanda, P. D., Barbetti, M. J., and Fitt, B. D. L. 2001. Epidemiology and management of Leptosphaeria maculans (Phoma stem canker) on oilseed rape in Australia, Canada and Europe. Plant Pathol. 50:10-27.

Wherrett, A. D., Sivasithamparam, K., and Barbetti, M. J. 2003. Chemical manipulation of Leptosphaeria maculans (blackleg disease) pseudothecial development and timing of ascospore discharge from canola (Brassica napus) residues. Aust. J. Agric. Res. 54:837-848.

Wherrett, A. D., Sivasithamparam, K., and Barbetti, M. J. 2004. Establishing the relationship of ascospore loads with blackleg (Leptosphaeria maculans) severity on canola (Brassica napus). Aust. J. Agric. Res. 55:849-854.

Wood, P. McR., and Barbetti, M. J. 1977. The role of seed infection in the spread of blackleg of rape in Western Australia. Aust. J. Exp. Agric. Anim. Husb. 17 1040-1044 